GIS - 理論と応用

Theory and Applications of GIS, 2019, Vol.27, No.1, pp.25-31

【研究・技術ノート】

東京都区部における建物名称に用いられる地名の滲出現象

小池 束紗* ·貞広 幸雄 ${ }^{* *}$ ・對間 昌宏***

\title{
EXUDING PHENOMENON OF PLACE NAME USED FOR BUILDING NAME IN TOKYO WARDS AREA
}

\author{
Tabasa KOIKE*, Yukio SADAHIRO**, Masahiro TAIMA***
}

\begin{abstract}
The image of region often is not identical with the actual boundary of the region, sometimes the image crosses over the boundary. In this study, we focus on the building name, which includes place name, and analyze about the determinants of place name exuding (exuding phenomenon). We use GIS data of 23 wards of Tokyo in Japan, and focus on the 934 place names to analyze the spatial distributions. Our findings show that railway-station, high-rise buildings, and large infrastructure (river) in the region influence the place names to cross over the region because they play as a symbol in the region. Moreover, we can see low-exuding-places are located around high-exuding-places, because high-exuding-places are distributed overall in Tokyo. The average distance of exuding is nearly the same as the distance of walk, and the distance of exuding is high near the boundary of Tokyo, because of the frequent use of car in the area. It is found that the image of region is relevant to the range of life and activity.
\end{abstract}

Keywords: 地名 (Place Name), 建物名称 (Building Name), 重回帰分析 (Multiple Regression Analysis)，空間分布 (Spatial Distribution)，東京都区部（Tokyo Wards Area）

\section{1.はじめに}

ある地名について人々が認識している領域は，当 該地域の行政区画の領域と必ずしも一致しない。都 市の成長・衰退や交通・情報通信などの社会基盤の 整備の進展に伴い, 人々の社会活動は行政区画を越 えて為される機会が多くなり, 地名がつけられた当 初と比較して, 地域の行政区画と人々が認識して いる領域はますます乘離してきている（谷口ほか, 1995)。今日では, 行政区画で規定されている領域 より, 人々の認識している領域の方が, 産業や公共 サービスにおいて関わりは大きいと考えられる。し たがって，現在においては行政区画に基づいた地域 計画では不十分なものとなっている.

上記のような状況においては行政区域のように主 に物理的に規定されていた地域よりも, 心理的に規 定される地域の方が地域計画での重要性が高まって
いる(谷口ほか, 1995)。ここで, 地域の認識の領 域を把握する意義を 3 点述べる。 1 点目として, 人々 の生活圏は交通基盤の整備の進展や産業構造の変化 に伴い，拡大をしている。拡大した生活圈に対応す るためにも，定住自立圈や道州制における取組や議 論で見られるように，隣接する地域は行政区域を 越えて公共サービスを共有し互いに支え合うため の，行政区域を越えた地域計画が重要である。つま り，市民の参加する地域計画においては，隣接地域 の計画との齟䶜が生じないためにも人々の認識して いる地名の領域を踏まえた検討が重要である。2点 目として，市町村合併に伴い，地域に対する住民の 誇りが失われていることが指摘されており（Odagiri, 2012），住民の地域の認識の領域を明らかにするこ とは適切な合併の実施の一助となると考えられる。 3 点目として, 地域イメージやブランドの一端は地

\footnotetext{
* 非会員 東京大学大学院新領域創成科学研究科社会文化環境学専攻 (The University of Tokyo) 干 113-8656 東京都文京区本郷 7-3-1 Tel：03-5841-8521 E-mail : tabasa0k@gmail.com 東京大学大学院新領域創成科学研究科社会文化環境学専攻 (The University of Tokyo) 
域の認識の領域に反映されていると考えると, 地域 に対するイメージは人々の行動（居住地選択や買い 物行動など）に多くの影響を与えているため, 地域 の認識の領域を把握することは重要である.

本研究では, 地域の認識の領域を捉える指標とし て, 地名が滲み出す現象（滲出現象）に着目する. 建物に地名を付与するという行為は, 建物の立地す る地点を当該地名で表現してよいと命名者が判断し た結果であり（大友ほか，2007）, 建物が当該地名 の行政区域外に立地していたとしても，建物に地名 が付与されることは, その建物の立地する地域まで その地名に対する人々の認識が広がっていると捉え ることができる。

地名に着目した既存研究では, 地区イメージの分 布や伝播の要因 (仲間, 1994), メンタルマップ（土 井ほか, 1995), 地名がつけられる範囲の経年変化 (谷口ほか, 1995; 谷口ほか, 1996), 町名や駅名に 備わるイメージ（倍田ほか, 1996), 人が認識して いる場所の領域（山崎ほか, 1997), 地区のイメージ, ブランド力（近藤ほか, 2001; 大佛ほか, 2004), 各 地名の命名の要因 (大友ほか, 2007) について研究 がなされてきている.いずれの研究においても, 建 物名称に地名が用いられる際には，何らかの意図が あると捉えられ，建物名称に用いられる地名の空間 分布は地名が指し示す地域のイメージや範囲が強く 影響していると示唆される.

既往研究における対象地としては世田谷区 (大佛 ほか, 2004)や自由が丘 (大友ほか, 2007), 京都市 (桐村, 2009)) など限られた地域で, 小規模な地域 に焦点が当てられることが多い，小地域を対象とす るため，建物に地名を命名する行為についてもその 地域の特性が大きく反映されており, その他の地域 についても同様の知見が得られるかについての検討 は不十分であるといえる。

本研究では, GISデー夕を用いることで, 東京都 23 区全域という既存研究と比較して非常に大規模 な地域を対象に, 建物名称に含まれる地名に着目し, 地域の行政区画を越えて, 地名が滲み出す（滲出） 現象に寄与する要因を定量的に明らかにすることを 目的とする。地名が滲出する要因としては物的な要
因（地域のランドマークや施設など）と質的な要因 (こ人々の生活圈やコミュニテイなど) があると想 定される，大規模な地域を対象とすることで，より 一般的な知見を得ることが期待できる.

\section{2. 研究方法}

\section{1. 対象地と対象地名}

対象地は東京都23区全域とする。建物名称に用 いられる地名は，最小の行政区分である大字（計 934大字）を用いることとする，その他の行政区分 である都道府県名, 区名や, 道路名, 坂名, 駅名, 公園などの施設名など建物名称に用いられる地名は 多く存在しているが，地域の認識の範囲を分析する ためのデータとして, 都道府県や区の規模の行政区 分だとだと地域数にそしく，地名の滲出に関して地 域間の比較が困難であり, 道路・坂・駅・公園では, 対象とする地域が限定的である。したがって統計的 手法に耐えうる地域数と建物数を十分取得可能な大 字名を用いて分析を行う。

\section{2. 使用データ}

建物に関するデータは，ゼンリンのデジタル住宅 地図, ZMAP TOWN II（2013）を使用する。各建物 は「個人の家屋」「名称のある建物」「事業所」「目標物」 の 4 つに分類されている。 このうち本研究では, 所 有者の意向によって建物名称が決定されると考えら れる「名称のある建物」を分析対象とする。「名称の ある建物」は東京都 23 区全体の建物数の $31 \%$ にあ たる 25 万 6786 棟ある。

\section{3. 大字名を持つ建物の抽出方法}

次に，大字名を名称に用いている建物（以下，地 名建物）を以下の方針で抽出する。

「代官山町」「相生町」など，末尾に「町」が付随す る大字名が建物名称に用いられる場合,「インペリ アル代官山」「ハイッ相生」などのように「町」を省 略することが多い，そこで，末尾に「町」がつく大 字名に関しては,「町」以外の大字名が建物名称に含 まれていれば地名建物と見なす。なお，「金町」「岸 町」「田町」などのように二文字の大字名に関しては, 「町」の省略は行われないため, そのままの大字名 が用いられている場合にのみ地名建物として扱う。 
また, 東京 23 区では,「新宿：しんじゅく(新宿区). にいじゅく(葛飾区)」「中町：なかちょう（新宿区・ 目黒区) ・なかまち（世田谷区）」「本町：ほんちょう (中野区・板橋区) ・ほんまち (渋谷区)」などのよう に, 読み方は異なるが, 同一の漢字を用いる大字名 が存在する。これらの大字間で各大字の地名を持つ 建物が一定の範囲内で混在している場合もあり, ど こまで各大字の地名が滲出しているか判断すること は困難であることから, 本研究では同一の漢字を用 いている大字を分析対象から排除することとする。

「コーポスミダ」,「HALEMA' OJIYUGAOKA」な ど, 地名がひらがな, カタカナ, ローマ字で表記さ れたものについては, 元の大字名を系統的に推定す ることが困難であることから, 本研究では分析の対 象外とする。

以上の手続きにより, 地名 802 大字, 建物 17 万 3324 棟が抽出された。 これらについて以下の分析 を行う。

\section{3. 結果と考察}

\section{1. 滲出度}

本節では, 地名が大字外の滲出している496大字 を対象として, 各大字の外部への滲出を分析する. ただし, 滲出距離の上限を定めずに分析したところ, 極端に滲出距離が大きく算出される大字があったた め, 滲出距離が $3000 \mathrm{~m}$ を超える場合には, 大字名を 参照していないものと見なし, 分析対象から除外す る。これは, 大字名が「桜」「椿」などの一般名詞や 固有名詞と一致している場合に相当する。なお既往 研究では, 大佛ら (2004) や近藤ら (2001) は $1500 \mathrm{~m}$ 〜2000mを上限としているが, 本研究はより広域を 対象としているため $3000 \mathrm{~m}$ を限とした。ただし， $3000 \mathrm{~m}$ 以内に上記の名詞を持つ建物については排除 できないが，そのようなケースは少数であるため分 析結果に大きな影響を与えないと仮定している.

ここで, 大字 $i$ の名称の滲出度 $R_{i}$ を, 大字 $i$ を含 む地名建物の総数 $n i$ と, そのうち大字 $i$ の外部の建 物数 $o_{i}$ を用いて, $R_{i}=O_{i} / n_{i}$ と定義する. 地名が滲出し ている大字は 496, 滲出度 $R_{i}$ の平均值は $0.273(496$ 大字) であった。大字ごとの滲出度を図 1 に示す (分
表 1 滲出度の基本統計量 (496大字)

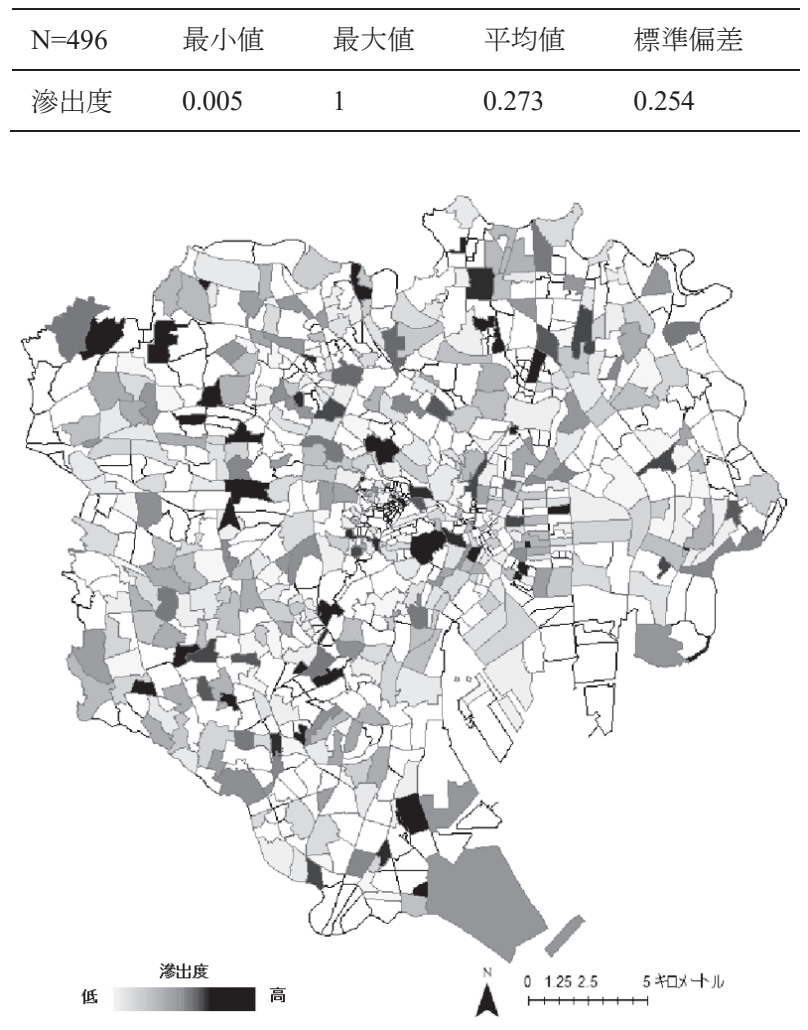

図 1 滲出度 $R_{i}$ の分布

析に用いていない大字については白色で示してい る). 滲出度の高い地域として, 大部分が公園や公 共施設用地で占められている大字 (駒沢公園, 平和 の森公園, 砧公園, 光が丘), 駅周辺の商業地域 (神 楽坂, 大門, 神田岩本町, 錦糸, 日本橋, 本木), 乗降客数の多い駅と同名の大字(秋葉原, 大塚, 中野, 目黒), 大部分が企業（物流, ホテルなど）の用地と して用いられている地域 (羽田旭町, 平和島, 戸塚 町), 名字として用いられる名称を用いる地域 (高 橋, 中村) がみられた。このように滲出度が非常に 大きい地域では, 周辺地域のシンボル（駅や公園な ど）が存在するとともに, それぞれの固有の状況（企 業用地, 駅前)によって, 地域内に地名がつく建物 が立地することが困難であることが重なり，地名の 滲出が著しく大きくなる傾向があった.

また，平均滲出度の大きな大字は 23 区内に全体 的に点在していて, 平均滲出度の大きな大字の周囲 は平均滲出度が比較的小さい大字に囲まれているこ とがわかる。一定範囲の地域においてイメージの良 さや有名さの理由で地名が特に滲出する大字が存在 
表2 滲出平均距離の基本統計量 (242大字)

\begin{tabular}{lllll}
\hline $\mathrm{N}=242$ & 最小值 & 最大值 & 平均值 & 標準偏差 \\
\hline 滲出平均距離 $(\mathrm{m})$ & 42.65 & 2292.25 & 391.72 & 351.01 \\
\hline
\end{tabular}

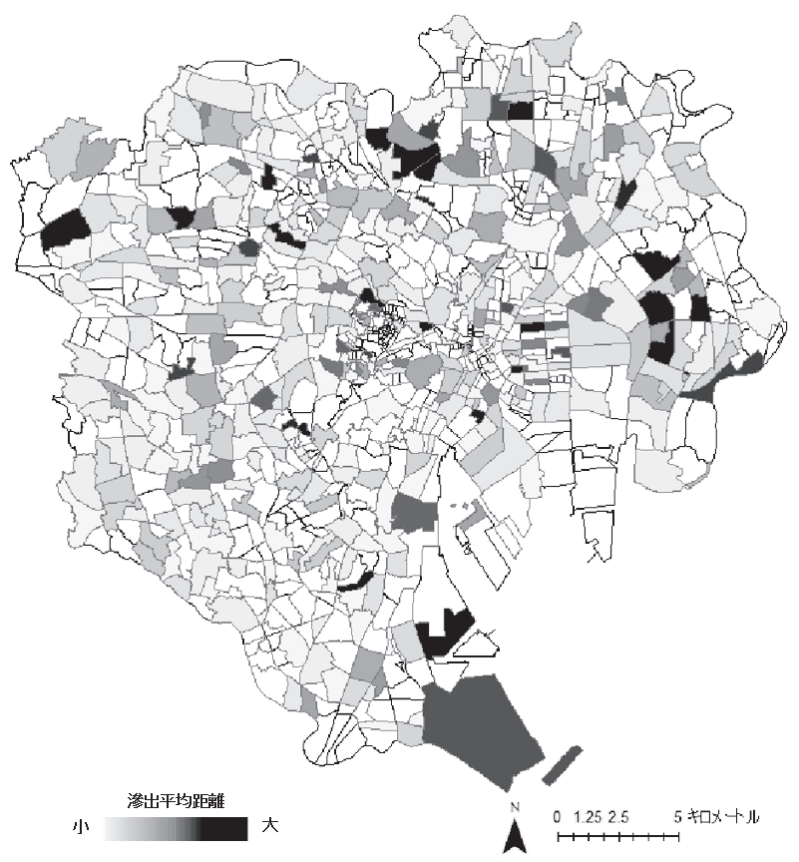

図2 大字ごとの滲出平均距離分布 (滲出建物 10 件以上の大字)

し, その周辺の地域の地名はあまり滲出しない構造 が想定される。近接する地域の人気の差によって, 地名の滲出の度合いが変化することは大友ら (2007) の自由が丘周辺の研究に拈いても言及されている. また，区名と同一の大字名が用いられる地域の滲出 度が大きい傾向があり, その背景として，区内全体 に建物が立地可能ということ以外に，あまり有名で ない大字などではよく知られている区名などを採用 する可能性が高いということも考えられる。

\section{2. 滲出距離}

次に, 地名建物の大字周辺への空間的広がりを分 析する。ここで, 地名建物の㳂出距離を大字の境界 と建物の重心との間の距離とする，滲出距離の上限 は, 節 3.1 . と同様に $3000 \mathrm{~m}$ とした。滲出距離 $3000 \mathrm{~m}$ 以下の建物について, 大字毎に渗出平均距離（滲出 距離の平均）を算出した結果を表2及び図 2 に示す （但し, 地名建物が 10 未満の大字は除外. 分析に用 いていない大字については白色で示している).

滲出平均距離の大きい地域の傾向として, 滲出度
の分析においても見られた, 乗降客数の多い駅周辺 の商業地域である地域 (有楽町)，大部分が企業の 用地として用いられている地域 (戸塚町) があった。 他に，一般的に良い印象を与える名称を持つ地域 (寿), 地域のシンボルとなる大きな川と同じ名称の 地域 (多摩川, 荒川, 江戸川) において滲出平均距 離が大きかった。 また, 滲出平均距離が大きい地域 の中には, 区名（豊島, 江戸川, 足立, 墨田, 世田谷, 台東，練馬，荒川）と同様の地名を持つ地域が多く 見受けられた。滲出度の場合も，区名の有無が滲出 に影響を与えているように見られたが，滲出距離で は，より顕著に影響が表れている。一般的な住宅街 で滲出平均距離が大きい地域として栗原, 大森中が あった。滲出距離の平均值は $391.72 \mathrm{~m}$ (242大字) と なっており, この数值は, 一般的な人の徒歩 5 分の 圈域 (不動産の表示に関する公正競争規約施行規則 に基づき徒歩 1 分当たり $80 \mathrm{~m}$ とした）である $400 \mathrm{~m}$ と 近い值となっている。このことから地域の認識の領 域は概ね徒歩 5 分圈と一致することが示唆される. これは，東京23区内の市民の多くが徒歩を主な交 通手段としていることが背景として考えられる。滃 出平均距離の大きい上位 10 大字は豊島・江戸川・寿・ 栗原 · 足立 - 墨田 - 世田谷 · 戸塚町 · 大森中 · 多摩 川であり,これらの地域は都心部(千代田区・中央区・ 港区）から比較的離れた東京の縁辺部に近い地域が 多くみられる。これは23区の都心から遠いほど交 通手段として自動車を用いることが多くなり，人々 の日常生活圈も広がることに伴い, 地域の認識の領 域も広がることが背景として考えられる。

\section{3. 滲出の要因}

前節に损いて, 大字ごとに渗出平均距離を求め, 各地域でどれほど建物が地域の外側に滲出している かについて分析を行った。しかし，区名や地域の状 況（敷地の大部分が企業の用地や駅前など）によっ て, 滲出度や滲出距離が大きい地域では, やむなく 地域外に地名がつく建物が立地すること多く，単に 地名のイメージが良いために地域外に滲出している わけではないことがわかった。滲出のメカニズムを 把握するためには, 様々な要因を考慮する必要があ る。そこで本節では, 重回帰分析 (ステップワイズ 
表3 滲出平均距離に関する回帰分析の結果

\begin{tabular}{|c|c|c|c|c|c|c|}
\hline \multirow[t]{2}{*}{ 変数 } & & \multicolumn{2}{|c|}{$\begin{array}{l}\text { 標準化されていない } \\
\text { 係数 }\end{array}$} & \multirow{2}{*}{$\begin{array}{l}\text { 標隻化 } \\
\text { 係数 } \\
\text { ベータ }\end{array}$} & \multirow[t]{2}{*}{$\mathrm{t}$ 值 } & \multirow[t]{2}{*}{$\mathrm{p}$ 值 } \\
\hline & & B & 標準誤差 & & & \\
\hline 区名 & $\begin{array}{l}\text { 1: 区名としても用いられる名称を用いている } \\
0 ： \text { 上記に当てはまらない }\end{array}$ & 919.855 & 76.397 & .599 & 12.040 & $.000^{* *}$ \\
\hline 名字 & $\begin{array}{l}\text { 1: 名字（東京都名字ランキング } 100 \text { 位以内） と } \\
\text { しても用いられる名称を用いている } \\
\text { 0：上記に当てはまらない }\end{array}$ & 246.672 & 96.072 & .127 & 2.568 & $.011^{*}$ \\
\hline 大字内同名駅 & $\begin{array}{l}\text { 1: 大字と同じ名称の駅が大字内にある } \\
0: \text { 上記に当てはまらない }\end{array}$ & -155.359 & 46.141 & -.168 & -3.367 & $.001 * *$ \\
\hline 第一種中高層住居専用地域 & $\begin{array}{l}\text { 1: 大字内に第一種中高層住居専用地域がある } \\
0 \text { ：上記に当てはまらない }\end{array}$ & -102.645 & 38.961 & -.137 & -2.635 & $.009^{* *}$ \\
\hline 第二種中高層住居専用地域 & $\begin{array}{l}\text { 1: 大字内に第二種中高層住居専用地域がある } \\
0 \text { ：上記に当てはまらない }\end{array}$ & -103.352 & 41.858 & -.125 & -2.469 & $.014^{*}$ \\
\hline 準住居地域 & $\begin{array}{l}\text { 1: 大字内に準住居専用地域がある } \\
0: \text { 上記に当てはまらない }\end{array}$ & 125.235 & 43.848 & .144 & 2.856 & $.005^{* *}$ \\
\hline
\end{tabular}

$*: \mathrm{p}<0.05, \quad * *: \mathrm{p}<0.01$

法）を用いて, 渗出距離に寄与する要因を分析する. 被説明変数は, 各大字の滲出平均距離, 説明変数は, 地名に関する既存研究 (大友ほか, 2007; 大佛ほか, 2004）で用いている変数を踏まえ，大字ごとの人口 (総人口, 世帯数), 面積, 地価, 公共施設 (公共施 設数, 駅数, 駅乗降客数, 小学校数), 都市計画規 制 (用途地域), 建物 (建物用途, 種類), 商業施設 (店舗数, 集客施設数), 観光資源, 区名, 名字 (名 字として多く用いられる名称）に関する変数を設定 した，結果は表3の通りである。表3から，滲出距 離に影響を与えている変数として6つあることがわ かり, そのうち滲出平均距離に正に作用する変数は, 区名，名字，準住居地域があり，負に作用するもの として大字内同駅名, 第一種中高層住居専用地域, 第二種中高層住居専用地域があることがわかった。 調整済み決定係数は 0.418 となっている.

準住居地域が，滲出平均距離に正に働く理由とし て，一般的に準住居地域は住居のほかに事務所・ テル・倉庫・自動車関連施設などが混在する地域で あり，建物が立地する面積が減少することで，地域 外に当該地名がつく建物が滲出していることが考え られる。

また，地名がつく事業所の存在が地名のイメージ の範囲を広げることは谷口ら（1995）が明らかにして おり, 道路沿いに指定された準住居地域内の事務所 によって, 滲出範囲が広くなったことも考えられる.

一方, 滲出平均距離に負の影響を与えている用途
地域として，第一種中高層住居専用地域，第二種中 高層住居専用地域があった。この結果から中高層の マンションが主な地域では，その地名を持つ建物が 外側に渗出しにくく，地域内に多く立地すると考え られる。中高層のマンションのような用途だと，多 くの利用者がおり，住所と異なる地名を用いること は，多くの人々に誤解と心理的な抵抗感を与えるこ とになりうることが背景として考えられる。中高層 住居の地域に加えて, 大字内同名駅も滲出平均距離 に負に働いていることがわかった。滲出度（節 3.1） や滲出距離（節3.2）の分析においても, 駅の存在 が滲出現象に対して大きな影響を与えていることが わかったが，滲出距離を大きくすることに対しては あまり寄与していない結果となった。この理由とし て, 駅は地域の大きなシンボルとなり, 地域のイメー ジの範囲をある程度大きくする効果があるが，建物 名称は最寄り駅の名称を付けることが一般的のた め, 一定距離以上離れると最寄り駅ではなくなって しまうことが挙げられる。また，秋葉原の例のよう に当該大字外に同一の名称を持つ駅が存在する場合 も多くあり，大字外に駅がある方が滲出距離を大き くすることに寄与したために，大字内に同名駅が存 在することで負の結果となったことが考えられる.

滲出度や滲出平均距離が大きい地域の中には, 乗 降客数が多いと考えられる駅と同様の名称を持つ地 域が，多くみられた。これは，大佛ら（2004）も同 一名の駅が地域のイメージを強く形成していること 
を明らかにしている．滲出平均距離を被説明変数と した重回帰分析において, 同名の駅が地域内に存在 する地域のみ（107地域）に限定し，同様の分析を 行うと, 滲出平均距離に対して, 駅の乗降客数が正 に有意 $(\mathrm{p}<0.05)$ に働くことがわかった. 駅の規模 が大きいほど, 利用する人は広範囲から通勤・通学 の目的で頻繁にアクセスするため, その駅の周辺一 帯に, その地名のイメージが広がると考えられる。

\section{4. おわりに}

本研究は, GISを用いて, 地域イメージに関する 既存研究と比較し非常に大規模な地域である23区 全域を対象として, 地名が滲出する現象に関する現 状の把握と要因の分析を行った。地名が渗出する現 象を把握することで, 地域の認識の領域の一端を捉 えることができた，本研究においては地名が大きく 滲出している地域がわかったが, そのような地域で は隣接地域まで含んだ地域計画の検討や, 地域ブラ ンドが高い可能性があり, 人々を惹きつける魅力が あることがわかる。また，東京都区部では市町村合 併の可能性は高くないが, 地方部においては同様の 手法を用いて地域の滲出状況を把握することで, 望 ましい市町村合併の検討に寄与する.

滲出の要因として, 駅は, 規模 (乗降客数) が大 きいほど, 地名の滲出を促す効果がある一方で特定 の大字内で同一名の駅が存在するとき地名の滲出に 負の影響があることや，マンションなどの中高層住 居地域は, 所在地の地名と異なる地名をつけない傾 向があり，地名が滲出しにくいことが明らかになっ た。

滲出度や滲出距離が大きい地域は，23区の全体 に点在していることから, 各地区において地名が特 に滲出する地域が存在し, その周辺の地域の地名は 滲出していない構造が想定される。また, 滲出距離 の平均值は, 概亦徒歩 5 分の圈域と一致しているこ とや，自動車を用いる機会が多い23区の縁辺部に 近づくにつれ, 滲出距離が大きくなっていることか ら, 地域の認識の領域は, 人々の交通手段や日常的 な生活圈の大きさと大きく関連することがわかっ た。
そして, 著しく地名が滲出する地域は, 周辺地域 のシンボル（駅や公園など）が立地するとともに, 特殊な地域の状況（敷地の大部分が企業の用地や駅 前など）によってやむなく地域外に建物が滲出する ことや，区名と同じ名称であることから地域を越え て広く同様の地名をもつ建物が立地することが示唆 された。

本研究の課題として, 東京の縁辺部に押いて地名 の滲出する範囲が広い可能性があり，この現象を客 観的に論証するためさらなる分析が必要となる。ま た，本研究では，駅，公園，川などの地域の施設に よる地名の滲出現象については, 大字名による地名 の㳂出現象の一部だと考えており，大字名と同一名 称の施設の存在によって地名の認識の領域が拡大す るものであると考えているが, 一方で駅や公園など の名称が特定の大字の地域を示す名称として人々に 認識されていない場合, 当該名称の広がりが地域の 認識の領域を示していないため, 地名が滲出してい るとは言えない場合がある。そして，限られたサン プル数が減少することを避けるため, 名字としても 用いられる名称の大字も分析で用いていたが, 正確 な地名の滲出現象を分析するためには十分なサンプ ル数を確保したうえで名字として多く用いられる地 名を排除した分析をするほうが望ましいと考えられ る.今回は, 建物用途を分類せずに地名に抽出を行っ たが，今後さらなる検討を行う際には，建物の用途 別に地名を分析することで，それぞれの違いをより 明確に示すことができると考えられる.

\section{謝辞}

本研究の分析に用いたデータは, 東京大学空間情 報科学センターからの提供を受けた。ここに記し謝 意を表する。

\section{参考文献}

Odagiri, T. (2012) Rural regeneration in Japan. Japan Local Government Centre, 1-41.

大友佑介・笠原知子 - 斎藤潮 (2007) 自由が丘駅周 辺を対象とした同一地名付建物名称の空間分布に 関する研究.「都市計画論文集」, 42 (3)，61-66. 
大佛俊泰 - 小川健一 (2004) 建物名称の空間分布か らみた地域イメージの魅力度分析.「日本建築学 会計画系論文集」，576，101-107。

桐村喬 (2009) 京都市に打ける地域名称を名称に含 む建物の空間分布に関する基礎的検討.「地理情 報システム学会講演論文集」，18，535-540.

近藤英心・浅見泰司 (2001) 建物名称に含まれる地 名の分布による地区ブランド力の分析.「地理情 報システム学会講演論文集」, 10, 39-44.

谷口守・荒木俊輔（1995）認識に基づく地域範囲設 定法とその経年的分析への応用.「土木学会論文 集」, 524, 59-67.

谷口守・荒木俊輔（1996）地名命名行為に着目した 認識上での地域間競争とその要因.「土木計画学 研究論文集」, 13, 225-232.
土井勉·木内徹·三星昭宏·北川博巳·西井和夫 (1995) 鉄道沿線における地域イメージの構造に関する研 究,「土木計画学研究論文集」, 12, 367-374.

仲間浩一 (1994) 地名呼称の分布に見る地区イメー ジの伝播に関する研究.「都市計画論文集」, 29 , 607-612.

倍田賢一.大佛俊泰 (1996) 建物名称の空間分布.「日 本建築学会大会学術講演梗概集」, 783-784.

山崎朱子 - 藤井明 - 曲㴊英邦 - 伊藤香織 (1997) 建 物名称分布にみる都市領域に関する考察.「日本 建築学会大会学術講演梗概集」, 627-628.

（2018年10月 5 日原稿受理, 2019年 1 月 12 日採用決定, 2019 年 3 月 15 日デジタルライブラリ掲載) 